\title{
Barbara Rdzanek
}

Uniwersytet Szczeciński

\section{Młodzież z niepełnosprawnością w kształceniu akademickim - możliwości i ograniczenia}

\section{Wprowadzenie}

Przełom XX i XXI wieku to okres intensywnych procesów kształtowania się społeczeństwa wiedzy. Kładzie ono szczególny nacisk na naukę i edukację. Edukacja jest wartością, zadaniem oraz ważnym narzędziem rozwoju każdego człowieka i społeczeństwa. Ludzie pozbawieni dostępu do wykształcenia stają się podmiotami wyizolowanymi nie tylko w życiu osobistym, lecz także w zbiorowej świadomości, a w konsekwencji są wykluczeni z prawidłowo funkcjonującej wspólnoty. Społeczeństwo informacyjne daje duże możliwości rozwoju, ale również generuje różne zagrożenia. Jednym z największych jest tworzenie się grup społecznych niemających dostępu do informacji - tzw. grup wykluczenia. Należą do nich osoby niewykształcone, o niskim statusie materialnym, bezrobotni oraz niepełnosprawni (Łukasiewicz, Unolid, 2000, s. 45). Wśród form działania przeciwko dyskryminacji osób z niepełnosprawnością jest aktywizowanie tej grupy społecznej przez tworzenie otoczenia bez barier. Niewątpliwą szansą na równoprawne funkcjonowanie w społeczeństwie informacyjnym osób niepełnosprawnych są studia wyższe. Niestety jest ona zbyt rzadko wykorzystywana. W roku akademickim 2014/2015 na uczelniach w Polsce studiowało 28 tys. osób z niepełnosprawnością - to zaledwie 1,5\% studenckiej społeczności akademickiej (Żyra, 2015, s. 23).

Taki stan rzeczy uwarunkowany jest ciągle jeszcze licznymi ograniczeniami i brakiem wsparcia społecznego dla włączania osób z niepełnosprawnością w nurt życia społecznego. Nie wystarczy sama ich wola i determinacja w dążeniu do uzyskania satysfakcjonującego miejsca w określonej społeczności akademickiej czy lokalnej wspólnocie. Niezbędna jest szeroko pojęta dostępność oraz stworzenie sprzyjających warunków funkcjonowania tej grupy osób. Owa dostępność to przede wszystkim niwelowanie barier tkwiących w kulturze społeczności lokalnej i społeczeństwa globalnego, rozwiązaniach organizacyjno-prawnych oraz w samej osobie z ograniczoną sprawnością. 
W tym kontekście edukacja na poziomie wyższym jawi się jako jeden z podstawowych środków skutecznej normalizacji życia osób z niepełnosprawnością (Ochonczenko, Czerwińska, Garbat, 2011, s. 5).

W niniejszym artykule przedstawiono działania z zakresu aktywizacji społecznej i zawodowej studentów z niepełnosprawnością podejmowane na uczelniach.

\section{Osoba z niepełnosprawnością}

Według definicji słownikowej student to osoba, która ukończyła szkołę średnią i otrzymała maturę, czyli dyplom potwierdzający ukończenie szkoły średniej (Szymczak, 1981, s. 890). Student (łac. studere - „starać się, przykładać się do czegoš") to uczeń szkoły wyższej, który podejmuje naukę w celu zdobycia lepszej pracy zawodowej (Cierpiałowska, 2009, s. 17). Jest to osoba kształcąca się na studiach pierwszego lub drugiego stopnia albo na jednolitych studiach magisterskich, która uzyskała ostateczną decyzję o przyjęciu na studia i złożyła ślubowanie określone w statusie uczelni.

Powyżej przedstawione definicje studenta są tylko przykładowe i bliskie pierwszym skojarzeniom, jakie nasuwają się nam, gdy słyszymy to określenie. Ale zastanówmy się dokładnie nad istotą bycia studentem. Student to przede wszystkim osoba, która ma już większe rozeznanie w tym, co chce robić w życiu. Jest to człowiek z konkretnymi przekonaniami i preferencjami. Pod ich kątem będzie wybierać kierunek swojej dalszej nauki i rodzaj uczelni. Jest to więc ktoś już bardziej świadomy samego siebie.

W Polsce, niezależnie od sposobu kształcenia, kierunku studiów czy stopnia niepełnosprawności, osoby niepełnosprawne są traktowane tak samo jak wszyscy inni studenci. Student $\mathrm{z}$ niepełnosprawnością, podobnie jak jego w pełni sprawni koledzy i koleżanki, zalicza sesje, uczestniczy w wykładach, realizuje program wynikający z toku studiów.

Warto w tym miejscu wymienić niektóre definicje osoby z niepełnosprawnością. Często przytaczane jest podejście proponowane przez Komitet Rehabilitacji i Readaptacji Człowieka Polskiej Akademii Nauk, w myśl którego osobą niepełnosprawną jest człowiek o naruszonej sprawności psychofizycznej powodującej ograniczenie funkcjonalne sprawności lub aktywności życiowej w stopniu utrudniającym pełnienie właściwych ról społecznych. Zbliżone stanowisko prezentuje Aleksander Hulek (1980, s. 18), przyjmując, że niepełnosprawną jest osoba, która na skutek ograniczeń pod względem fizycznym (motorycznym, sensorycznym), somatycznym lub psychofizycznym ma znaczne trudności w wywiązywaniu się z zadań, jakie stawia przed nią życie codzienne, szkoła, praca zawodowa. Z kolei Tadeusz Majewski (1994, s. 35) definiuje osobę niepełnosprawną jako jednostkę, u której istotne uszkodzenie i obniżenie sprawności funkcjonowania organizmu powoduje utrudnienie, ograniczenie czy uniemożliwienie wykonywania zadań życiowych i wypełniania ról społecznych, biorąc pod uwagę jej wiek, płeć oraz czynniki społeczne, środowiskowe i kulturowe. Osoba niepełnosprawna, której stan fizyczny lub psychiczny trwale lub okre- 
sowo utrudnia, ogranicza albo uniemożliwia wypełnianie zadań życiowych i ról społecznych zgodnie z normami prawnymi i społecznymi, wymaga wsparcia i pomocy innych osób (Dykcik, 1997, s. 47). Na ten aspekt w definicji osoby niepełnosprawnej zwraca uwagę m.in. Światowa Organizacja Zdrowia, według której osoby niepełnosprawne nie są w stanie o własnych siłach zaspokajać istotnych potrzeb, wchodzić optymalnie w role społeczne i wymagają pomocy z zewnątrz (Sowa, 2000, s. 47).

W krajach Unii Europejskiej coraz bardziej upowszechnia się stanowisko, w myśl którego osobą niepełnosprawną jest jednostka w pełni swych praw, znajdująca się w sytuacji upośledzającej ją na skutek barier środowiskowych, ekonomicznych, społecznych i kulturowych, których z powodu występujących u niej uszkodzeń nie może przezwyciężać w taki sposób jak inni ludzie (Chan, Zoellick, 1995, s. 134).

Charakterystyczne dla przytoczonych definicji jest wskazywanie na mniejsze w porównaniu $\mathrm{z}$ osobami sprawnymi możliwości i wynikające $\mathrm{z}$ tego faktu problemy natury zarówno osobistej, jak i społecznej, wśród których bardzo mocno zaznaczają się zaburzenia rozwojowe powodujące wiele ograniczeń funkcjonowania i niejednokrotnie skazanie na bycie uzależnionym od pomocy osób i instytucji.

Należy jednak pamiętać, że osoby niepełnosprawne mają także liczne i różnorodne możliwości, co nie powinno dziwić, z uwagi na dominację cech wspólnych osób niepełnosprawnych i pełnosprawnych. Za potencjałem osób niepełnosprawnych przemawia to, że przecież różnice między ludźmi są czymś naturalnym i każda osoba ponosi wysiłek związany z wypełnianiem zadań życiowych. W przypadku osób niepełnosprawnych z reguły jest to wysiłek zdecydowanie większy, gdyż oprócz tego, że muszą one pokonać swoje słabości, zmagają się także niejednokrotnie z dotkliwszymi społecznymi konsekwencjami swej niepełnosprawności (Ochonczenko, Czerwińska, Garbat, 2011, s. 141).

\section{Znaczenie wykształcenia dla osób z niepełnosprawnością}

Kwestia społecznej integracji dzieci z niepełnosprawnościami doczekała się licznych opracowań, niewiele natomiast jest prac dotyczących funkcjonowania osób niepełnosprawnych kształcących się na uczelniach wyższych. Wśród przyczyn takiej sytuacji znajdują się przekonania na temat ograniczonych możliwości kształcenia osób niepełnosprawnych na poziomie wyższym, generalnie niższy odsetek uczniów niepełnosprawnych funkcjonujących w systemie edukacji integracyjnej, niska solaryzacja osób niepełnosprawnych. Struktura kształcenia uczniów niepełnosprawnych w systemie integracyjnym ma kształt piramidy na poziomie przedszkolnym ich liczba jest znacząca, w szkołach średnich bardzo niewielka, na studiach zaś minimalna (Dryżałowska, 2003, s. 54-55). Posiadanie wykształcenia, a następnie realizowanie się $\mathrm{w}$ roli zawodowej, nie ukazuje pełni możliwości osoby naznaczonej piętnem niepełnosprawności. Dzięki powyższym osoba niepełnosprawna czuje, że może realizować różnorodne role społeczne mimo ewidentnych ograniczeń. Wykształco- 
nym, pracującym niepełnosprawnym o wiele łatwiej zachować poczucie sensu życia, dobre samopoczucie, wysoką samoocenę, jak również poczuć się wartościowym i godnym szacunku innych (Ochonczenko, Czerwińska, Garbat, 2011, s. 144).

Za kształceniem osób niepełnosprawnych na poziomie wyższym przemawiają zarówno potrzeby i możliwości tych ludzi, jak i argumenty humanitarne oraz prawne, a także ekonomiczne. W przypadku osób niepełnosprawnych studia wyższe - może nawet w większym zakresie niż w odniesieniu do osób pełnosprawnych - stanowią istotną drogę do samorealizacji, osiągania określonego (wymarzonego) statusu życiowego, mogą kompensować różnego rodzaju braki i - co najważniejsze - przeciwdziałają społecznej izolacji (Pilecki, Olszewski, Parys, 2000, s. 107). Edukacja na poziomie wyższym służy zatem nieskrępowanemu rozwojowi człowieka uczestniczącego w procesie kształcenia, oferuje mu możliwości zdobywania własnego systemu wartości, daje szansę nabycia bogatych doświadczeń społecznych i wypróbowania się w nowych rolach społecznych, umożliwia odebranie wykształcenia potwierdzonego dyplomem. Studiujące, dobrze wykształcone i wykonujące atrakcyjną pracę osoby niepełnosprawne to dowód na pełną realizację akcentowanych $\mathrm{w}$ pedagogice specjalnej zasad normalizacji i integracji oraz idei niezależnego życia osób dotkniętych różnymi dysfunkcjami organizmu, a także uregulowań prawnych obecnych w codziennym życiu tych osób (Bąbka, 2005, s. 56). Edukacja akademicka nie ogranicza się do wymiaru indywidualnego. To również społeczny wymiar kształcenia, gdyż edukacja sama w sobie jest wartością społeczną służącą rozwojowi społeczeństwa, jej istotą zaś jest przekazywanie dorobku nauki, kultury, prezentacja dokonań ludzkości we wszystkich dziedzinach wiedzy, przekaz tradycji, przygotowanie kadry o najwyższych kwalifikacjach (Bąbka, 2005, s. 60).

Udział studentów z niepełnosprawnością w realizacji tak istotnych ogólnospołecznych celów edukacji na poziomie szkolnictwa wyższego pozwala też na zmianę wizerunku osoby niepełnosprawnej. Już uzyskanie dyplomu wyższej uczelni przez osobę niepełnosprawną wpływa na zmianę sposobu jej percepcji przez otoczenie. Niepełnosprawność wówczas staje się relatywnie mniej istotna, a na pierwszy plan wysuwa się osiągnięcie człowieka ukończenie studiów wyższych (Pilecki, Olszewski, Parys, 2000, s. 108).

\section{Student z niepełnosprawnością w społeczności akademickiej}

Przyjęcie w poczet studentów uniwersytetu następuje z chwilą immatrykulacji i złożenia ślubowania przed dziekanem. Wypowiadane drżącym głosem słowa ślubowania uświadamiają przekraczającym próg uczelni, że oto rozpoczynają kolejny etap w swoim życiu, wchodzą w nieznaną sobie rzeczywistość, w której przyjdzie im funkcjonować w nowej roli - studenta. By stać się studentem, kandydat musiał wcześniej przejść pomyślnie procedury rekrutacyjne (złożyć komplet wymaganych dokumentów). 
Z kolei, aby zaistnieć na uczelni w roli studenta niepełnosprawnego, należy przedstawić dokument orzekający o niepełnosprawności oraz dokumentację medyczną potwierdzającą problemy zdrowotne. Studenci z niepełnosprawnością podlegają temu samemu regulaminowi studiów, co studenci pełnosprawni. Zgodnie z Regulaminem studiów na Uniwersytecie Szczecińskim wszystkim studentom przysługuje to samo prawo: student ma prawo do zdobywania wiedzy, rozwijania własnych zainteresowań naukowych oraz przygotowania się do wykonywania określonych zawodów w kulcie prawdy, sumiennej pracy i atmosferze wzajemnej życzliwości. Oprócz możliwości korzystania z praw przysługujących studiującym wszyscy studenci zobowiązani są do postępowania zgodnego z treścią ślubowania, regulaminem studiów oraz innymi przepisami obowiązującymi na uczelniach. U podstaw wypełniania obowiązków leży świadomość zakresu własnych obowiązków i gotowość do poniesienia wysiłku związanego z realizacją zasad studiowania. Nie bez znaczenia są także realne możliwości wypełniania obowiązków wynikające ze specyficznej sytuacji życiowej studenta. Może się on znaleźć w trudnej dla siebie sytuacji życiowej ograniczającej (okresowo lub trwale, w różnym zakresie i stopniu) normalne funkcjonowanie oraz pełną realizację roli społecznej. Regulamin studiów uwzględnia takie sytuacje, traktuje je jako ważne okoliczności losowe lub trudne sytuacje życiowe. Wśród sytuacji szczególnych wymienia się m.in. niepełnosprawność, długotrwałą chorobę, samodzielne wychowywanie dziecka oraz trudną sytuację materialną (Regulamin, 2015).

Umiejscowienie w systemie edukacji uczelni wyższych dla wszystkich daje każdemu studentowi możliwość pełnego udziału w społeczeństwie i kulturze, zdobycia wyższego wykształcenia zawodowego i tym samym większe szanse zaistnienia na rynku pracy. Uczelnie wyższe wypracowują model równych szans w dostępie do edukacji, odpowiadają na potrzeby ogółu społeczeństwa. Przyjmując powszechne stanowisko, że szczególne okoliczności, w jakich znalazł się student (w tym student niepełnosprawny), stanowią podstawę do udzielenia mu wsparcia i pomocy:

1. To podanie pomocnej dłoni studentowi wynika z jego trudnej sytuacji życiowej, której sam nie jest w stanie przezwyciężyć.

2. W dobie humanitaryzacji życia wrażliwość na potrzeby innych osób, okazywana im pomoc i życzliwość są czymś naturalnym i zarazem koniecznym, widoczna jest też potrzeba stworzenia całej sieci wsparcia osób niepełnosprawnych.

3. Edukacja równych szans.

4. Zasada indywidualnego podejścia (Ochonczenko, Czerwińska, Garbat, 2011, s. 147-148). Kwestia, w której student niepełnosprawny może liczyć na uwzględnienie jego specyficznej sytuacji życiowej, dotyczy wielu istotnych elementów studiowania:

1. Planu, programu i organizacji studiów - student może studiować według indywidualnego planu studiów i programu nauczania. W uzasadnionych przypadkach (np. osoba niepełnosprawna, zdarzenie losowe) może się ubiegać o zastosowanie indywidualnej organizacji studiów. 
2. Udziału w programach studenckich, np. Erasmusie, dostępnym także dla studentów niepełnosprawnych, uwzględniającym m.in. dodatkowe fundusze na wyjazd oraz asystę osoby pomagającej.

3. Udziału w turnusach rehabilitacyjnych organizowanych przez uczelnie.

4. Możliwości ubiegania się o stypendium specjalne dla osób niepełnosprawnych - niezależnie od uzyskania prawa do innych form pomocy materialnej (Ochonczenko, Czerwińska, Garbat, 2011, s. 148).

\section{Formy wsparcia podejmowane przez uczelnie na rzecz osób niepełnosprawnych}

Jedną z form działania przeciw dyskryminacji osób z niepełnosprawnością jest aktywizowanie tej grupy społecznej poprzez tworzenie otoczenia bez barier. Ta idea przyświeca wszystkim uniwersytetom od momentu powołania ich do życia. Misją uniwersytetów jest kształcenie, także osób niepełnosprawnych. Uczelnie wyższe przykładają dużą wagę do wypracowania modelu równych szans osób z niepełnosprawnością w dostępie do edukacji. Dlatego podejmują różne inicjatywy pozwalające na lepsze funkcjonowanie osób niepełnosprawnych.

\section{Instytucja Pomocnika Rektora ds. Niepełnosprawnych Studentów}

Według encyklopedycznej definicji pełnomocnik jest osobą uprawnioną do dokonywania czynności prawnych w imieniu i na rzecz mocodawcy (Kaczorowski, 2004, s. 891). Jest rodzajem przedstawiciela, który ma prawo dokonywania czynności prawnych w imieniu osoby reprezentowanej. $Z$ jednej strony powinien reprezentować interesy niepełnosprawnych studentów oraz liczyć się z opinią społeczności akademickiej, z drugiej zaś musi działać według pewnych zasad społecznych, czyli przestrzegać obowiązującego prawa. Działalność pełnomocnika określona jest zapisami w ustawach o szkolnictwie wyższym (Ustawa, 2005) oraz rehabilitacji (Ustawa, 1997). W wymienionych aktach prawnych określono zakres i obowiązki odnośnie do kształcenia i rehabilitacji studentów niepełnosprawnych.

Pełnomocnik Rektora ds. Niepełnosprawnych Studentów od początku ich funkcjonowania na uczelni wyższej skupia się na wielu istotnych dla nich kwestiach. Informuje o możliwościach kształcenia się osób niepełnosprawnych na uczelni, odpowiada na wiele pytań, udziela porad, zachęca do podjęcia wyzwania, jakim jest studiowanie, jednocześnie zapewnia o pomocy w przypadku trudności. Aktywność pełnomocnika ma na celu przede wszystkim ułatwienie studentom niepełnosprawnym dostępu do uzyskania wyższego wykształcenia przez dostosowanie wymogów formalnych i struktur administracyjnych do ich potrzeb oraz usuwanie barier w dostępie do zasobów informacyjnych i zajęć dydaktycznych. Ważnym obszarem działania pełnomocnika jest propagowanie programów 
PFRON, w ramach których studenci ze znacznym i umiarkowanym stopniem niepełnosprawności mogą się ubiegać o zwrot kosztów związanych z dojazdem na uczelnie, zakwaterowaniem, czesnym za studia, zakupem przedmiotów ułatwiających studiowanie (np. komputery, drukarki). Ponadto monitoruje aktualnie realizowane programy i środki docelowe, służące wyrównywaniu szans edukacyjnych osób niepełnosprawnych. Podejmuje działania integrujące i promujące środowisko studentów niepełnosprawnych, a także kształtujące przychylne postawy społeczności akademickiej wobec nich. Jest również odpowiedzialny za wymianę doświadczeń między uczelniami krajowymi i zagranicznymi $\mathrm{w}$ zakresie podnoszenia jakości usług oferowanych niepełnosprawnym studentom $\mathrm{w}$ ramach posiadanych aktualnie możliwości (Ustawa, 2005, art. 7-10).

Wśród funkcji pełnionych przez Pomocnika Rektora ds. Niepełnosprawnych Studentów możemy wyróżnić:

1. Funkcję informacyjną, która obejmuje dwa aspekty. Pierwszy dotyczy informowania opinii publicznej o problemach oraz działaniach z tego wynikających. Drugi sprowadza się do stworzenia pewnego centrum informacyjnego dla niepełnosprawnych studentów.

2. Funkcję diagnostyczną polegającą na rozpoznaniu, określeniu i wyłonieniu zjawisk społecznych dotyczących niepełnosprawnych studentów. Funkcja ta obejmuje też analizę skali i siły oddziaływania tych zjawisk.

3. Funkcję integracyjną polegającą na prowadzeniu działań przyczyniających się do petniejszej integracji niepełnosprawnych studentów ze społecznością akademicką.

4. Funkcję koordynującą wynikającą z funkcji inicjującej, która polega na uwzględnianiu i harmonizowaniu działań na rzecz osób niepełnosprawnych z innymi organizacjami.

5. Funkcję regulacyjną odnoszącą się do ujednolicenia działań na rzecz niepełnosprawnych studentów na uczelni (Ustawa, 2005, art. 11-13).

\section{Rada Studentów Niepełnosprawnych}

Rada Studentów Niepełnosprawnych zrzesza studentów zainteresowanych problemem niepełnosprawności występującym w środowisku akademickim. Ta grupa młodych ludzi reprezentuje interesy studentów niepełnosprawnych, podejmuje czynności mające na celu wyrównywanie szans oraz prowadzi działania z zakresu rehabilitacji, integracji społecznej i działalność informacyjną. Poprzez wspólną aktywność w zakresie likwidacji barier architektonicznych i mentalnych członkowie rady starają się rozwiązywać problemy swych niepełnosprawnych kolegów. Biorą udział we wszelkich działaniach mających na celu polepszenie wizerunku osób niepełnosprawnych i ułatwienie im edukacji na poziomie akademickim. Do Rady Studentów Niepełnosprawnych należeć może każdy, komu realizowane przez nią przedsięwzięcia są bliskie i komu zależy na prawie funkcjonowania osób niepełnosprawnych oraz na tym, aby pobyt na uczelni kojarzył się im z czymś więcej niż tylko ze studiowaniem (Ochonczenko, Czerwińska, Garbat, 2011, s. 212). 


\section{Wsparcie procesu dydaktycznego}

Nadrzędnym celem działalności jest umożliwienie studentom z niepełnosprawnością pełnego uczestnictwa w procesie dydaktycznym oraz życiu społecznym, naukowym i kulturalnym, a nawet sportowym uczelni. Nie chodzi tu o tworzenie przywilejów, ale o wyrównywanie szans edukacyjnych osób o różnych rodzajach niepełnosprawności i pozostałych studentów od momentu postępowania rekrutacyjnego, aż po rozpoczęcie pracy zawodowej przez absolwenta. W tym celu konieczne są działania zmierzające do likwidowania barier architektonicznych, informacyjnych, komunikacyjnych i psychologicznych utrudniających studiowanie.

Metody i formy kształcenia są dobierane elastycznie w zależności od indywidualnych potrzeb studenta. W miarę potrzeb poszukuje się optymalnego rozwiązania w danej sytuacji. Należy tutaj podkreślić, iż każdy problem zgłoszony przez studenta traktowany jest indywidualnie, pod kątem niezbędnej pomocy oraz aktualnych możliwości uczelni w tym zakresie. W razie potrzeby student może liczyć na pomoc i wsparcie psychologa.

Po wcześniejszym zgłoszeniu takiej potrzeby przez studenta Pełnomocnik Rektora ds. Niepełnosprawnych Studentów, opierając się na ustalonej procedurze formalnej, pomaga opracować indywidualną strategię egzaminu dostosowaną do potrzeb i możliwości danej osoby. Alternatywna forma egzaminu nie oznacza obniżenia progu wymagań wobec studenta, a jedynie techniczną adaptację. Studenci z niepełnosprawnością mogą się ubiegać o zmianę form egzaminów i zaliczeń, która polega na możliwości zamiany formy pisemnej na ustną, zwiększenia czasu trwania egzaminu, zdawania przy pomocy formularzy wydrukowanych inną wielkością czcionki, komputera lub z pomocą asystenta. Alternatywna forma zdawania egzaminów oznacza dostosowanie jej do specyficznych potrzeb wynikających z niepełnosprawności studenta (Ochonczenko, Czerwińska, Garbat, 2011, s. 212-213).

\section{Trudności, na jakie napotykają osoby niepełnosprawne}

Mimo wielu ułatwień zwiększających możliwości funkcjonowania osób z niepełnosprawnością w roli studenta istnieją także liczne bariery, które sprawiają, że osoby niepełnosprawne mogą się czuć ograniczone w wypełnianiu swych funkcji. W kontekście warunków akademickich warto natomiast przyjrzeć się mechanizmom natury społecznej, które mogą sprawić, że wypełnianie roli studenta przez osoby z niepełnosprawnościami będzie stwarzać pozory poprawności, szczególnie jeśli chodzi o relacje interpersonalne. Wśród tych mechanizmów wymienić należy: izolację, segregację, dyskryminację, marginalizację, stygmatyzację, stereotypy. Wszystkie powodują pomniejszenie wartości osoby z niepełnosprawnością, a co za tym idzie - jej gorsze funkcjonowanie w wymiarze indywidualnym i społecznym. Szczególnie niebezpieczna jest izolacja, będąca zaprzeczeniem idei integracji pozbawiającym osoby niepełnosprawne możliwości uczestniczenia w normal- 
nym życiu oraz narażającym na przeżywanie negatywnych stanów emocjonalnych (np. samotności). Równie niebezpieczne dla osób niepełnosprawnych jest ich funkcjonowanie $\mathrm{w}$ warunkach segregacji, kiedy w ramach jednego społeczeństwa na podstawie wcześniej ustalonych kryteriów, często wynikających z irracjonalnych przesłanek, jedne grupy ludzkie odizolowują się od drugich, co powoduje, że niektóre grupy niepełnosprawnych, wyłonione najczęściej przy uwzględnieniu kryterium rodzaju lub stopnia niepełnosprawności, powinny bytować w swoim własnym świecie, niezależnie od ogółu społeczeństwa (Dunaj, 1996, s. 1007).

Dyskryminacja powoduje, że odmienność osoby jest traktowana jako jej wada, która musi być okupiona cierpieniem, poniżaniem, prześladowaniem, szykanowaniem. Dyskryminując osoby niepełnosprawne, odmawia się należnych im praw, pomniejsza się ich znacznie, narażając je na wykluczenie z życia społecznego lub bytowanie na jego marginesie. Osoby niepełnosprawne doświadczają także stygmatyzacji i etykietowania. Silnie przeżywają deprywację związaną z bezsilnością uniemożliwiającą wyrwanie się z kręgu mechanizmów utrudniających adaptację społeczną z niemożnością zaspokajania silnie odczuwanych potrzeb fizjologicznych, psychicznych i społecznych (Kantyka, 2002, s. 17).

Dodatkowym utrudnieniem dla niepełnosprawnych są stereotypy dotyczące niepełnosprawności i osób nią dotkniętych. Te funkcjonujące w świadomości społecznej obrazy rzeczywistości oraz fałszywa wiedza o osobach z niepełnosprawnością często przekazywane są bezrefleksyjnie. Przeraża też, że osoby posługujące się stereotypami nie dążą do osobistego wyrobienia sobie opinii na temat osób niepełnosprawnych: ich rzekomej słabości, niezaradności, izolowania się, wycofywania, uzależnienia od pomocy innych. Wolą nie wchodzić $w$ bezpośrednie relacje z niepełnosprawnymi, a jeśli już utrzymują takie kontakty, nacechowane są one uprzedzeniami społecznymi krzywdzącymi najczęściej osoby niepełnosprawne. Wynikiem funkcjonowania tych wszystkich mechanizmów społecznych w środowisku życia osoby niepełnosprawnej jest wytworzenie się negatywnych postaw społecznych wobec niej: obojętności (kiedy unika się kontaktów z osobami niepełnosprawnymi lub sprowadza się je do sporadycznych, przypadkowych, chłodnych, niezobowiązujących sytuacji), odrzucenia (gdy unika się jakichkolwiek kontaktów, jawnie okazuje się lekceważenie, nie szanuje się potrzeb wynikających z niepełnosprawności osoby, jednocześnie demonstruje się przewagę związaną z posiadaną sprawnością), agresji (kiedy osoby niepełnosprawne doświadczają werbalnych zaczepek, złośliwości, utrudnień, agresji słownej, a nierzadko fizycznej; Kawczyńska-Butrym, 1996, s. 76).

Drugą grupą barier, o których likwidację być może jeszcze trudniej, są bariery natury psychologicznej, tkwiące w samych osobach z niepełnosprawnościami, związane z doświadczaniem własnej niepełnosprawności i siebie w roli osoby niepełnosprawnej. Ból, cierpienie, często poczucie braku sensu życia, bezradności i uzależnienia od innych, niepewność jutra, niepokój, lęk, przerażenie, panika, rozpacz, żal, zamknięcie się w sobie, apatia, rozdrażnienie, agresja - tak wiele emocji towarzyszy człowiekowi w jego byciu niepełnosprawnym (Ochonczenko, Czerwińska, Garbat, 2011, s. 154). 
Przebieg procesu przystosowania do niepełnosprawności (akceptacji niepełnosprawności i siebie jako osoby niepełnosprawnej) zależy od wielu różnorodnych czynników, a mianowicie od sposobu doświadczania niepełnosprawności, momentu jej doznania, płci oraz rodzaju aktywności życiowej. Jest to proces złożony, zazwyczaj długotrwały, stanowi podstawę funkcjonowania osoby $\mathrm{z}$ niepełnosprawnościami zarówno $\mathrm{w}$ wymiarze indywidualnym (osobniczym), jak i społecznym (Nowicka, Bąbka, 2010, s. 56).

\section{Podsumowanie}

W dziedzinie kształcenia akademickiego widoczne jest coraz częstsze odchodzenie od segregacyjnych form kształcenia studentów z niepełnosprawnością i wprowadzanie form integracyjnych wspartych różnymi usługami społecznymi. Należy pamiętać o tym, iż osoby niepełnosprawne realizują się dzięki temu, że mogą się rozwijać, zmieniać, uczyć i pracować, współprzeżywać z innymi, tworząc społeczność akademicką. Takie podejście leży u podstaw rozmaitych działań podejmowanych przez uczelnie wyższe. $Z$ jednej strony mają one na celu likwidację barier, a z drugiej aktywizację niepełnosprawnych w życiu społecznym. Działania na rzecz studentów niepełnosprawnych koordynuje i inicjuje Pełnomocnik Rektora ds. Niepełnosprawnych Studentów. Powinien on dostrzegać bariery, problemy i rozumieć innych ludzi, szczególnie tych po wypadkach i z bardzo ciężkimi dysfunkcjami, ponieważ one wymagają specjalnego podejścia. Jest to spowodowane tym, że każdy człowiek doświadczony przez życie ma obniżone poczucie własnej wartości (Ochonczenko, Czerwińska, Garbat, 2011, s. 223).

Dostęp osób niepełnosprawnych do studiów wyższych powiązany jest ściśle ze stworzeniem im pełnych możliwości uczestnictwa w życiu społecznym, a co za tym idzie wdrażaniem zasad równego traktowania. Konstytucja RP stanowi, że wszyscy obywatele są równi wobec prawa, zasada ta rozciąga się również na sferę szkolnictwa wyższego. Konstytucyjne prawo do nauki jest współcześnie, w dobie gospodarki opartej na wiedzy, jednym z podstawowych praw człowieka postrzeganym zarówno jako dobro i wartość indywidualna, jak i dobro społeczne.

\section{Bibliografia}

Bąbka, J. (2005). Edukacyjny kontekst psychospołecznego funkcjonowania studentów niepełnosprawnych. W: H. Ochonczenko, G. Miłkowska (red.), Osoba niepetnosprawna w społeczności akademickiej (s. 56 - 69). Kraków: Wydawnictwo Impuls.

Cierpiałowska, T. (2009). Studenci z niepetnosprawnościa - problemy funkcjonowania edukacyjnego i psychologicznego. Kraków: Wydawnictwo Naukowe UP.

Dryżałowska, G. (2003). Integracja edukacyjna a integracja społeczna uczniów niepełnosprawnych. Zeszyty Naukowe WSSM w Suwatkach, 8, 54-55. 
Dunaj, B. (1996). Słownik wspótczesnego języka polskiego. Warszawa: Wydawnictwo Wilga.

Dykcik, W. (1997). Wprowadzenie w przedmiot pedagogiki specjalnej jako nauki. W: W. Dykcik (red.), Pedagogika specjalna (s. 47-61). Poznań: Wydawnictwo UAM.

Hulek, A. (1980). Problemy psychologiczne $w$ rehabilitacji inwalidów. Warszawa: Wydawnictwo Państwowy Zakład Wydawnictw Lekarskich.

Kaczorowski, B., Baturo, W. (red.), (2004). Nowa encyklopedia powszechna PWN. Warszawa: Wydawnictwo Naukowe PWN.

Kantyka, S. (2002). Podmiotowość osób niepełnosprawnych - idea niezależnego życia. W: L. Frąckiewicz (red.), Postawy wobec niepetnosprawności (s. 17-30). Katowice: Wydawnictwo Akademii Ekonomicznej.

Kawczyńska-Butrym, Z. (1996). Niepetnosprawność - specyfika pomocy społecznej. Warszawa: Wydawnictwo Interart.

Łukasiewicz, R., Unold, J. (2000). Monopolizacja dostępu do informacji w procesie globalizacji. W: U.M. Grześkowiak (red.), Społeczeństwo informacyjne przyjazne dla osób specjalnej troski (s. 47-60). Szczecin: Wydawnictwo Naukowe US.

Majewski, T. (1994). W sprawie definicji osoby niepełnosprawnej. Problemy Rehabilitacji Społecznej i Zawodowej, 1, 35-49.

Nowicka, A., Bąbka, J. (2010). Człowiek i jego rodzina wobec utraty zdrowia i sprawności. Lublin: Wydawnictwo Akademickie Żak.

Ochonczenko, H., Czerwińska, M., Garbat, M. (2011). Osoby z niepetnosprawnością w szkole wyższej. Zielona Góra: Wydawnictwo Uniwersytetu Zielonogórskiego.

Pilecki, J., Olszewski, S., Parys, K. (2000). Kształcenie osób niepełnosprawnych w szkole wyższej. W: A. Rakowska, J. Baran (red.), Dylematy pedagogiki specjalnej (s. 107-121). Kraków: Wydawnictwo Naukowe Akademii Pedagogicznej.

Regulamin (2015). Regulamin Studiów na Uniwersytecie Szczecińskim. Pobrane z: http://www. wzieu.pl/imgs_2/regulaminy_uchwaly/regulamin_2015_16.pdf (29.12.2017).

Sokołowska, M. (1985). Sytuacja ludzi niepetnosprawnych $i$ stan rehabilitacji w PRL. Wrocław: Wydawnictwo Zakład Narodowy im. Ossolińskich.

Sowa, J. (2000). Pedagogika specjalna w zarysie. Rzeszów: Wydawnictwo Fosze.

Szymczak, M. (1981). Słownikjęzyka polskiego. Warszawa: Wydawnictwo Naukowe PWN.

Ustawa (1997). Ustawa z dnia 27.08.1997 r. o rehabilitacji zawodowej i społecznej oraz zatrudnieniu osób niepełnosprawnych. Dz.U. z 1997 r., nr 123, poz.776.

Ustawa (2005). Ustawa z dnia 27.07.2005 r. Prawo o szkolnictwie wyższym. Dz.U. z 2005 r., nr 164, poz.1365.

Żyra, M. (2015). Szkoty wyższe i ich finanse w 2014 r. Pobrane z: https://stat.gov.pl/files/gfx/portalinformacyjny/pl/defaultaktualnosci/5488/2/11/1/szkoly_wyzsze_i_ich_finanse_w_2014.pdf (30.12.2017). 


\title{
Streszczenie
}

W ciągu ostatnich lat postawy społeczne wobec osób niepełnosprawnych zmieniają się w kierunku pozytywnym. Zwiększa się otwartość osób pełnosprawnych na osoby z niepełnosprawnością oraz wzrasta świadomość, że brak odpowiednich udogodnień na poziomie edukacji wyższej skutkuje nie tylko obniżeniem kwalifikacji zawodowych osób niepełnosprawnych, lecz także odebraniem im możliwości wyrównania różnic w obszarze umiejętności społecznych, komunikacyjnych i zawodowych. W przypadku osób niepełnosprawnych studia wyższe może nawet $\mathrm{w}$ większym zakresie, niż gdy mówimy o osobach pełnosprawnych, stanowią istotną drogę do samorealizacji, osiągania określonego statusu życiowego, mogą kompensować różnego rodzaju braki i - co najważniejsze - przeciwdziałają społecznej izolacji.

Słowa kluczowe: student, osoba z niepełnosprawnością, student niepełnosprawny

\section{YOUTH WITH DISABILITIES IN ACADEMIC EDUCATION- OPPORTUNITIES AND LIMITATIONS}

\begin{abstract}
Summary
Over the years, social attitudes towards people with disabilities have changed in a positive direction. The openness of non-disabled people to disabled people increases and the awareness is growing that the lack of appropriate facilities at the higher education level results not only in lowering the professional qualifications of disabled people, but also taking away the possibility of equalizing differences in the area of social, communication and professional skills. In the case of people with disabilities, higher education can even to a greater extent than when we talk about non-disabled people are an important way to selffulfillment, achieve a specific life status, can compensate for various deficiencies and most importantly counteract social isolation.
\end{abstract}

Keywords: student, person with disability, disabled student 